INTERNATIONAL HIGHER EDUCATION - NUMBER 66 WINTER 2012 Pages 27-29.

Chile: The Rise and Decline of a Student Movement

Andrés Bernasconi

Andrés Bernasconi is a scholar of higher education policy and administration and the Academic Vice Rector of Universidad Andrés Bello, in Chile. E-mail: abernasconi@unab.cl.

Shortly after the beginning of the academic year in March, Chilean university and high school students took their grievances to the streets and unleashed what the leaders of the movement like to describe as the largest popular demonstrations since the return to democracy, in 1990.

In Chile, as in most of Latin America, university student protests have been a staple of the social movement's scenario. Since the 1980s, higher education in Chileprivate and public—is funded chiefly through tuition payments by students. Thus, in the past two decades, facing increasing costs of tuition, the mobilized students had regularly pushed for more student aid and obtained it. But these demonstrations were brief and focused. A novelty first emerged in 2006, when public high school students, demanding better education in the public sector, went on strike and barricaded themselves in dozens of schools-effectively interrupting classes for thousands in several of the main cities of Chile, bringing down the Minister of Education, and turning the quality of education into a political crisis that lasted for several months. 
This year's student movement follows in the wake of the 2006 riots but has achieved greater scope and depth. Its support has extended way beyond the most politically active students, who had typically led and galvanized their peers, involving at its peak a majority of public opinion. The transformations the movement seeks to leverage are not just changes in education but in the "model" of development Chile has been enacting for the past 30 years.

What began as the expected seasonal rioting of high school pupils (only deferred last year, due to the earthquake in southern Chile) acquired momentum when university students joined in the taking of buildings and organized weekly massive marches on the streets of downtown Santiago and other major cities. For the past six months, numbers sometimes approaching 200,000 have marched to demand fundamental changes in Chile's educational system, and more. Hundreds of schools and college buildings have been occupied by live-in demonstrators and classes forcefully suspended—for some 250,000 high school students (7\% of the national total) and for most public universities, whose students went on strike.

\section{ORIGINS OF THE UPRISING}

The educational demands of the students mix well-worn banners-such as more funding for public universities-and greater access of underprivileged populations, with newer and more fundamental proposals—such as the reform of the municipal administration of primary and secondary public schools, the ending of for-profit education at all levels, and the introduction of tuition-free higher education for all. 
Several factors have contributed to ignite and sustain the protests. The weakness of popular support for the rightist government of President Sebastián Piñera, with poll numbers hovering in the low 30s, leaves the government with little legroom for a political solution of the problem.

The charisma of the two main spokespersons for the movement-Camila Vallejo, president of the Student Federation of the University of Chile, and Giorgio Jackson, president of the Student Federation of the Catholic University of Chile-has provided the movement with agreeable and articulate faces and helped leverage the students' cause with the national and international media.

Some rectors of public universities have also contributed to the climate of exasperation, by denouncing the paucity of public spending in the state sector of higher education-about half the average level of Organization for Economic Cooperation and Development countries. Rectors have sometimes accused the private sector of higher education, which accounts for $3 / 4$ of all postsecondary enrollments, of profiteering, elitism, or substandard quality. While this portrayal of the private sector is a caricature, it has played well with ample sectors of society that are not particularly fond of the private provision of public goods and, instead, long for greater state control of education, health, energy, or infrastructure.

Lastly, there appears to be a good measure of frustration among the Chilean middle class, with the neoliberal model of development that Chile has followed since the years of General Pinochet's dictatorship (with marginal corrections during the 20 years ruled by a coalition of left-of-center parties). The "model" has done good for Chile's economic growth, and for the very poor, for a whole generation. However, its 
individualistic and competitive overtones and a growing sense of overall social inequality, which includes but is not limited to educational opportunity, seems to be subjecting the social compound to severe stress. Popular solidarity with the students is nurtured by this complex social environment.

\section{PeAK AND Decline}

In part, as a reflection of this generalized malaise and, also, out of sheer political opportunism, other aggrieved groups joined secondary and university students in the streets-such as the teachers' union, a newly created association of debtors of university loans, government employees, and the national union of workers.

In late July, the movement achieved a political victory, by forcing the president to remove the minister of education. The new minister invited the leaders of the students to discuss a policy-reform proposal, encompassing all levels of education. For higher education, the government was offering quite likely the most generous package ever put on the table in 40 years, both in terms of financial commitments and in response to the historic demands of the educational actors: the proposal considered injecting additional US $\$ 4$ billion ( $2 \%$ of gross domestic product) to the educational budget over a period of 4 to 6 years, which would fund increased access to preschool, reforms in schools of education to improve teacher training and certification, changes in the governance of public school districts, and increased per student funding for $\mathrm{K}-12$ education.

In higher education, the government offered to create an enforcement agency to protect students' rights, monitor accountability, and ensure universities to abide by 
their nonprofit status. It also proposed strengthening of the national accreditation commission and its procedures-as well as more to the core of the students' agenda, increase funding for public universities, ease loan payment conditions for outstanding debtors, lower the interest rate on educational loans, and give full-tuition scholarships to the poorest 40 percent of students.

The government did not, however, offer to eliminate for-profit private education (let alone private education, as a whole) or to make higher education free of tuition. More generally, the government is reluctant to change the model of subsidy to students' demand, through vouchers, scholarships, and loans-under which financial support is channeled both to school education and higher education.

The students remained unmoved. Mere adjustments to the educational system would not suffice. They want to transform what they see as Chile's "free market," "neoliberal" education-as a means of changing the Chilean free market, neoliberal model of development. They believe that well-funded, state-run education can achieve better outcomes for students and a more inclusive, cohesive, and just society. Their response to the government was a pledge to continue and radicalize the movement.

The expansion of the student movement, to include other causes, added to its influence, but that stage blurred its agenda and turned it increasingly ideological and politicized. Its success in garnering the support of public opinion clouded the judgment of the students' leadership and their political advisers, who at this critical juncture chose to exchange actual reform for the chance of affecting a transformation in capitalism itself. 
The government reacted by taking back what it had offered, transferring its responsibility, of finding a solution, to congress and the discussion therein of the budget bill for 2012, and betting on the progressive erosion of the movement. The gambit is paying off: exhaustion with the violence often associated with the protests is eating on popular support for the movement; rectors are eager to grab what the government offered and are for the first time, in six months, putting pressure on students to go back to classes; some of the leaders face elections in their student federations; and the press is moving on to other issues.

The movement's unprecedented success conspires with its effectiveness. With grand and ever-evolving goals, multiple and diffuse leaderships, political radicalization among many of its constituents, and mounting damage to public schools and universities from six months of paralysis-the movement seems increasingly unable to find an acceptable endgame. The student movement has brought the problems of education to the forefront of the political agenda-no small feat, even if it's the only one this gesture can manage to accomplish. 